\title{
Trans-generation study of the effects of nonylphenol ethoxylate on the reproduction of the snail Biomphalaria tenagophila
}

\author{
Eduardo Cyrino Oliveira-Filho ${ }^{\mathrm{a}, *}$, Cesar Koppe Grisolia ${ }^{\mathrm{b}}$, \\ Francisco Jose Roma Paumgartten ${ }^{\mathrm{c}}$ \\ ${ }^{a}$ Laboratory of Ecotoxicology, Embrapa Cerrados, Rod. BR020, Km 18, Planaltina DF 73310-970, Brazil \\ ${ }^{\mathrm{b}}$ Institute of Biology, University of Brasilia, Brasilia DF 70910-900, Brazil \\ ${ }^{\mathrm{c}}$ Laboratory of Environmental Toxicology, Department of Biological Sciences, National School of Public Health, Oswaldo Cruz Foundation (FIOCRUZ), \\ Rio de Janeiro, RJ 21041-210, Brazil
}

Received 25 January 2007; received in revised form 16 October 2007; accepted 21 October 2007

Available online 3 December 2007

\begin{abstract}
Nonylphenols ethoxylates (NPEs) are surfactants used in a variety of products. They are found in domestic sewage, industrial effluents and as contaminants in water bodies. This study was undertaken to evaluate the effects of NPE with 9.5 ethoxylate units (NPE9.5; 0, $0.01,0.1,1.0 \mathrm{mg} / \mathrm{L})$ on the reproduction of the snail Biomphalaria tenagophila. Adult snails $\left(F_{0}\right.$ generation) were exposed to NPE for 8 weeks. The $F_{1}$ generation continued to be exposed from embryo to reproductive maturity while their descendants $\left(F_{2}\right)$ were exposed until day 10 after spawning. We determined the effects of NPE9.5 on the fecundity (8-week production of eggs and egg masses) of mature $F_{0}$ and $F_{1}$ snails. Developmental toxicity was investigated in $F_{1}$ and $F_{2}$ embryos. The two highest concentrations of NPE9.5 reduced the fecundity of $F_{0}$. In the $F_{1}$ generation, the lowest concentration enhanced the number of eggs laid per snail while the intermediate concentration had no effect and the highest one decreased the fecundity thereby suggesting a biphasic effect of NPE9.5. Study-derived NOECs (no-observed-effect-concentrations) for NPE were: fecundity, $F_{0}=10 \mu \mathrm{g} / \mathrm{L}, F_{1}<10 \mu \mathrm{g} / \mathrm{L}$; developmental toxicity, $F_{1}=100 \mu \mathrm{g} / \mathrm{L}$, $F_{2}<10 \mu \mathrm{g} / \mathrm{L}$. Results, therefore, indicated that $B$. tenagophila is highly vulnerable to NPE and that trans-generation exposure to NPE9.5 aggravates its reproductive toxicity.
\end{abstract}

(C) 2007 Elsevier Inc. All rights reserved.

Keywords: Toxicity tests; Chronic toxicity; Invertebrates; Ecotoxicology; Estrogens; Xenoestrogens; Endocrine disruptors; Reproduction; Snails

\section{Introduction}

Nonylphenol ethoxylates (NPEs) are non-ionic surfactants widely used as emulsifiers in industrial and household cleaning agents, agricultural chemicals, and plastic polymerization process. NPEs have been found in domestic sewage and industrial effluents and, where sewage and effluents are not treated, they are released directly into water bodies (Maguire, 1999). Several studies have reported relatively high levels of nonylphenol ethoxylates in aquatic ecosystems (Bennie, 1999) and sub-lethal concentrations of NP and shorter chain NPEs have been reported to impair the reproductive performance of aquatic

\footnotetext{
${ }^{*}$ Corresponding author. Fax: +55216133889879.

E-mail address: cyrino@cpac.embrapa.br (E.C. Oliveira-Filho).
}

species, an adverse effect that has been attributed to the estrogenic activity of these environmental contaminants (Servos, 1999). The reproductive toxicity of NP and NPEs has been described in a variety of fish species (Jobling et al., 1996; Archand-Hoy and Benson, 1998; Routledge et al., 1998; Larsson et al., 1999; Willey and Krone, 2001), but there are only a limited number of studies on their effects on the reproduction of invertebrates.

Some studies have found that sub-lethal concentrations of NPEs, NP, and other putative endocrine disruptors are harmful to marine mollusks (Matthiessen and Gibbs, 1998; Depledge and Billinghurst, 1999; Horiguchi et al., 2002; Nice et al., 2003; Porte et al., 2006), but their effects on freshwater snails have been far less investigated. The present study was undertaken to investigate the effects of nonylphenol ethoxylate (NPE9.5) on the reproductive 
performance of the freshwater snail Biomphalaria tenagophila in successive generations.

\section{Material and methods}

\subsection{Test organism}

Biomphalaria tenagophila (Orbigny, 1835) is a freshwater pulmonate snail (Mollusca, Gastropoda) found in Brazilian water bodies where it is one of the intermediate hosts of Schistosoma mansoni. Owing to their importance in the transmission of schistosomiasis in the New World, biology and ecology of snails belonging to Biomphalaria genus have been intensively studied. Since Biomphalaria snails are also easily bred and kept under laboratory conditions, their use in ecotoxicity assays has been suggested by several authors (Ravera, 1977; Bellavere and Gorbi, 1981; Münzinger, 1987; Oliveira-Filho et al., 2004, 2005). All snails used in the experiments were from the breeding stock of B. tenagophila maintained at the Department of Ecology from the University of Brasilia (UnB).

\subsection{Assay water, test substance and nominal concentrations}

The nonylphenol ethoxylate 9.5 (RENEX 95, nonylphenol with 9.5 ethoxylate units, NPE9.5) used in this study was supplied by BASF, Brazil. All snails were kept in a synthetic softwater $(\mathrm{pH} 7.2 \pm 0.1$, hardness $40-48 \mathrm{mg} / \mathrm{L}$ as $\mathrm{CaCO}_{3}$ ) prepared as recommended by guidelines of the Brazilian Association for Technical Standardization (ABNT, 2004). NPE9.5 was dissolved directly in the assay water at the following nominal concentrations: $0.01,0.1$, and $1 \mathrm{mg} / \mathrm{L}$. Short-term exposures to the tested concentration range of NPE9.5 were expected to be non-lethal because in a previous acute toxicity test with $B$. tenagophila (adult), we had found that NPE9.5 96-h $\mathrm{LC}_{50}(95 \% \mathrm{CL})$ was $6.39(4.16-9.32) \mathrm{mg} / \mathrm{L}$ (OliveiraFilho et al., 2005).

\subsection{Experimental design}

\subsubsection{Effects on the fecundity of the parental generation $\left(F_{0}\right)$}

Three-month-old snails were individually exposed to NPE9.5 (10 snails per concentration) in glass vessels of $300 \mathrm{~mL}$ and kept under controlled environmental conditions $\left(25 \pm 1{ }^{\circ} \mathrm{C}\right.$ and light/dark cycle $\left.16 / 8 \mathrm{~h}\right)$. The assay water was renewed twice a week and snails were fed with fresh lettuce leaves cultivated without using pesticides (a piece of approximately $1 \mathrm{~cm}^{2}$ ) plus $1 \mathrm{mg}$ of a laboratory-made chow per snail. The chow was prepared as described by Freitas et al. (1997). To recover egg masses laid by snails, glasses were internally covered with cellophane sheets. Cellophane sheets were changed twice a week and numbers of eggs and egg masses per snail were recorded. Egg production of $F_{0}$ generation snails exposed to NPE9.5 was evaluated for 8 consecutive weeks.

\subsubsection{Developmental toxicity and effect on the fecundity of the first generation $\left(F_{1}\right)$}

Egg masses laid by parental snails ( $F_{0}$ generation) after an 8-week exposure period, chosen at random, were separated to be exposed - to the same concentrations of NPE9.5 - during the embryonic development and post-hatching growth of the subsequent $\left(F_{1}\right)$ generation of snails. A first group was separated for the evaluation of developmental toxicity of the NPE9.5 ( $F_{1}$ embryos) and the remaining ones continued to be exposed during post-hatching growth until reproductive maturity when they were about 3 months old. These mature $F_{1}$ generation snails (10 per concentration) were used for the evaluation of the effects of NPE9.5 on egg production (fecundity) and were also the source of egg masses used to investigate the developmental toxicity on the subsequent generation of snails $\left(F_{2}\right.$ embryos).

Developmental toxicity was evaluated in four to five egg masses (approximately 100 embryos) per concentration group. The endpoints for developmental toxicity were embryolethality, incidence of malformations, and delay of hatching. All egg masses selected for evaluation of developmental toxicity were examined daily under a stereomicroscope. Malformed embryos were identified by using the criteria described by Geilenkirchen (1966). Malformed embryos were living embryos that were swollen (hydropic), had a head or shell abnormality as well as all those embryos with any other abnormal development not classifiable as head, shell, or hydropic malformations (i.e., unspecific malformations). We had previously noted that, under normal conditions, all unexposed $B$. tenagophila snails hatch within 10 days of spawning. Therefore, delay of hatching was indicated by the proportion of live embryo snails that did not hatch until day 10 after spawning.

\subsubsection{Developmental toxicity in the second generation $\left(F_{2}\right)$}

Evaluation of developmental toxicity in $F_{2}$ embryos (egg masses laid by $F_{1}$ snails) was performed as previously described for the $F_{1}$ embryos.

\subsection{Statistical analysis}

Differences in the number of eggs and egg masses produced, as well as proportions of dead embryos, malformed embryos, and embryos that did not hatch were evaluated by one-way ANOVA followed by Dunnett's multiple comparison test. Data shown as proportions were transformed (arc sine square root) before performing the parametric analysis.

\section{Results}

\subsection{Effects on the reproductive performance of $F_{0}$ generation}

The effects of 8-week exposure to NPE9.5 on the fecundity of $B$. tenagophila parental generation $\left(F_{0}\right)$ are shown in Figs. 1 and 2. Exposure to NPE9.5 caused, at the two highest concentrations $(0.1$ and $1.0 \mathrm{mg} / \mathrm{L})$ tested, a marked reduction in the number of eggs produced per snail $($ mean \pm S.E.; $0.1 \mathrm{mg} / \mathrm{L}=417.6 \pm 72.9 ; \quad 1.0 \mathrm{mg} / \mathrm{L}=362.1 \pm$ $28.7 \mathrm{eggs} /$ snail) as compared to the number of eggs laid by unexposed snails $(675.6 \pm 58.2 \mathrm{eggs} / \mathrm{snail})$. NPE9.5

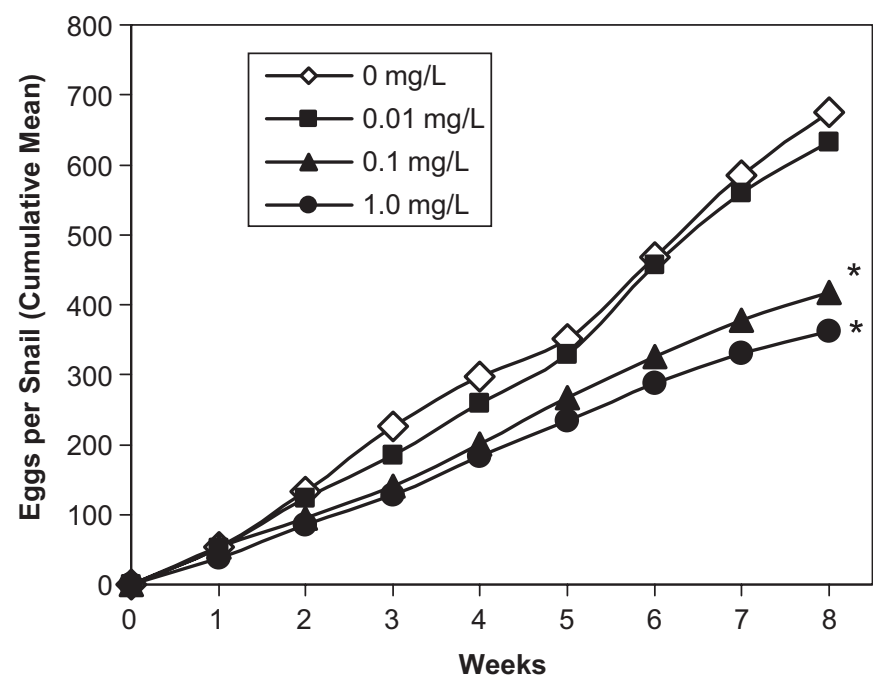

Fig. 1. Effects of nonylphenol ethoxylate with 9.5 units $(0,0.01,0.1$, and $1.0 \mathrm{mg} / \mathrm{L})$ on the number of eggs laid by mature $B$. tenagophila snails $\left(F_{0}\right.$ generation). Data are shown as cumulative means of number of eggs laid per snail during an 8-week exposure. An asterisk (*) indicates that the mean differ $(p<0.05$ ANOVA and Dunnett's multiple comparisons test) from that of unexposed controls $(0 \mathrm{mg} / \mathrm{L})$ at the 8 th week. 


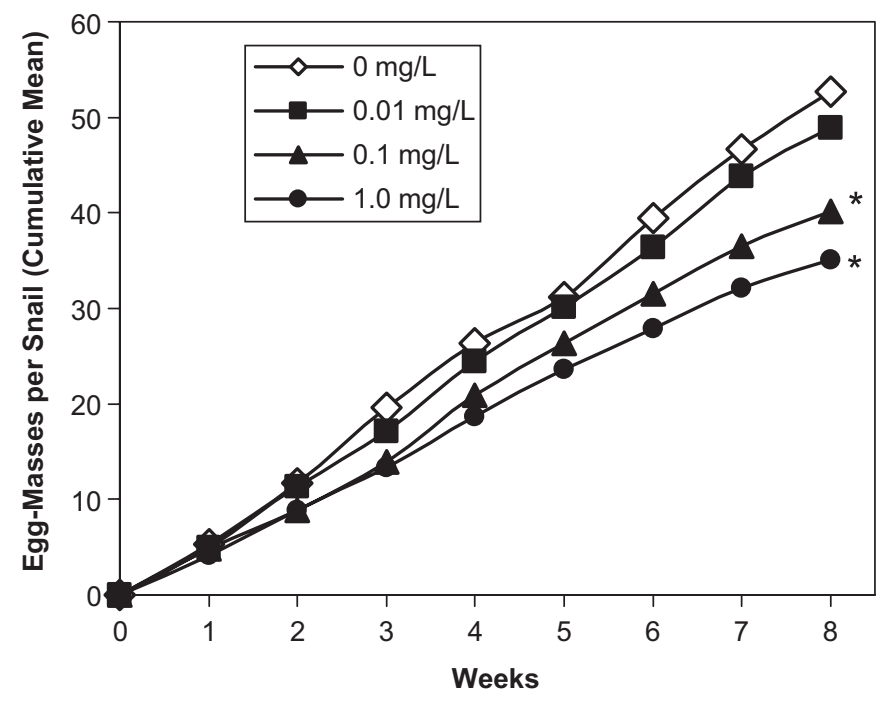

Fig. 2. Effects of nonylphenol ethoxylate with 9.5 units $(0,0.01,0.1$, and $1.0 \mathrm{mg} / \mathrm{L})$ on the number of egg masses laid by mature $B$. tenagophila snails $\left(F_{0}\right.$ generation). Data are shown as cumulative means of number of egg masses laid per snail during an 8-week exposure. An asterisk (*) indicates that the mean differ ( $p<0.05$ ANOVA and Dunnett's multiple comparisons test) from that of unexposed controls $(0 \mathrm{mg} / \mathrm{L})$ at the 8 th week.

induced decrease of egg production resulting - to a great extent - from a smaller number of egg masses laid by snails during the exposure period (mean \pm S.E.; $0 \mathrm{mg} / \mathrm{L}=52.7 \pm$ $2.7 ; 0.1 \mathrm{mg} / \mathrm{L}=39.8 \pm 2.2 ; 1.0 \mathrm{mg} / \mathrm{L}=35.0 \pm 1.3$ egg-masses/ snail). No difference of egg production was noted between snails exposed to the lowest concentration of NPE9.5 tested $(0.01 \mathrm{mg} / \mathrm{L})$ and the unexposed controls.

\subsection{Effects on the $F_{1}$ generation: developmental toxicity and fecundity}

The exposure of the $F_{1}$ generation of snails to NPE9.5 encompassed embryonic development and post-hatching growth up to reproductive maturity when the effect on egg production (fecundity) was evaluated.

The effect of NPE9.5 on the embryonic development of the $F_{1}$ generation of $B$. tenagophila was evaluated in a subgroup of egg masses produced by the parental $F_{0}$ generation (four to five egg masses, i.e., approximately 100 eggs per concentration). Egg masses were examined under a stereomicroscope and developmental toxicity of NPE9.5 was investigated by determining the proportion of dead embryos (embryolethality), the incidence of malformed snails (teratogenicity), and the proportion of hatching (hatching delay) until day 10 after spawning. We found no statistically detectable difference between unexposed controls and NPE9.5 exposed groups regarding the incidence of deaths and the proportion of hatchings (Figs. 3 and 4). Nevertheless, an augmented incidence of malformed individuals - as compared to the incidence in unexposed controls - was found in snails from the egg

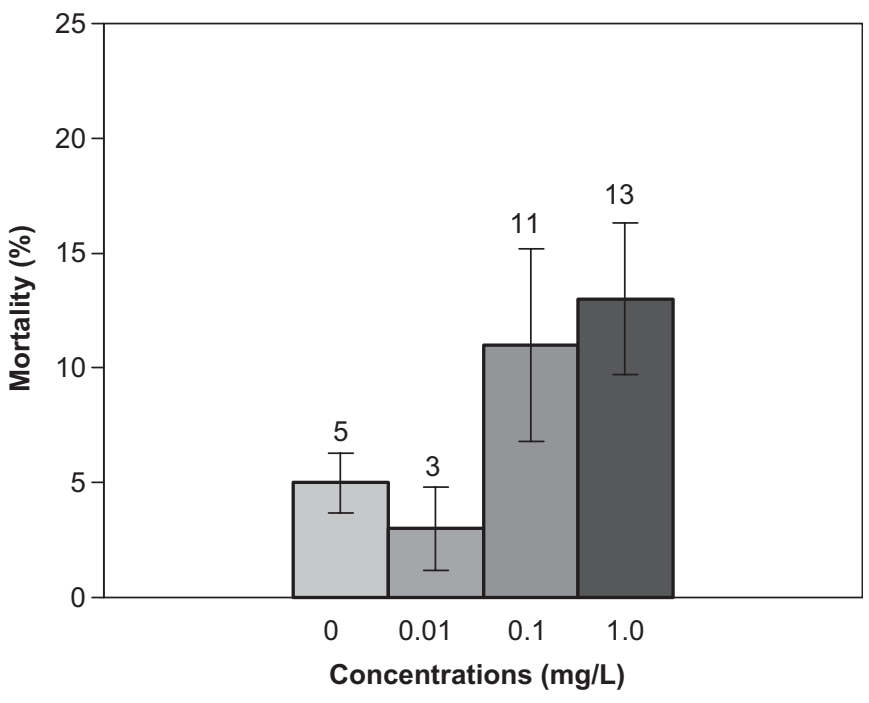

Fig. 3. Embryolethal effects of nonylphenol ethoxylate with 9.5 units $(0,0.01,0.1$, and $1.0 \mathrm{mg} / \mathrm{L})$ on $B$. tenagophila embryos $\left(F_{1}\right.$ generation $)$ recorded at the 10th day after spawning. Proportions are means \pm S.E. of embryo deaths $(($ no. of deaths $/$ no. of eggs $) \times 100)$ per egg mass. No difference was found ( $p<0.05$ ANOVA and Dunnett's multiple comparisons test) between any group exposed to NPE and unexposed control group $(0 \mathrm{mg} / \mathrm{L})$.

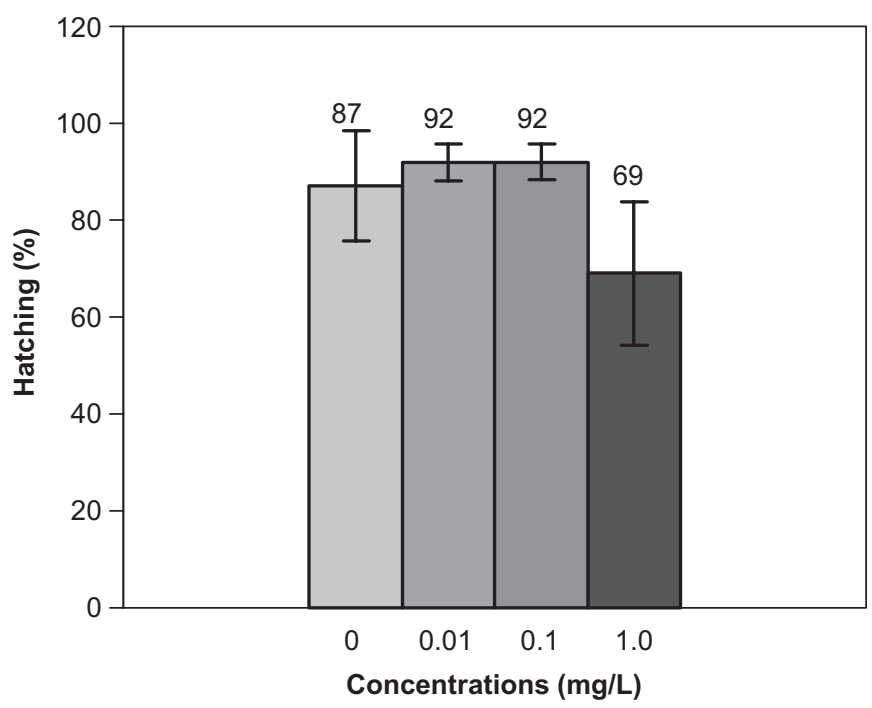

Fig. 4. Proportion of hatching until the 10th day after spawning ( $F_{1}$ generation embryos) exposed to nonylphenol ethoxylate with 9.5 units $(0,0.01,0.1$, and $1.0 \mathrm{mg} / \mathrm{L})$. Values are means \pm S.E. of percentages of hatching ((no. of successfully hatched snails/no. of eggs $) \times 100)$ per egg mass. No difference was found ( $p<0.05$ ANOVA and Dunnett's multiple comparisons test) between any group exposed to NPE and unexposed control group $(0 \mathrm{mg} / \mathrm{L})$.

masses exposed to the highest concentration of NPE9.5 (Fig. 5).

The effect of exposure to NPE9.5 on the reproductive performance of the $F_{1}$ generation was examined in individuals originated from another sub-group of egg masses produced by the $F_{0}$ generation of $B$. tenagophila snails. After hatching, snails were grown in collective glass 


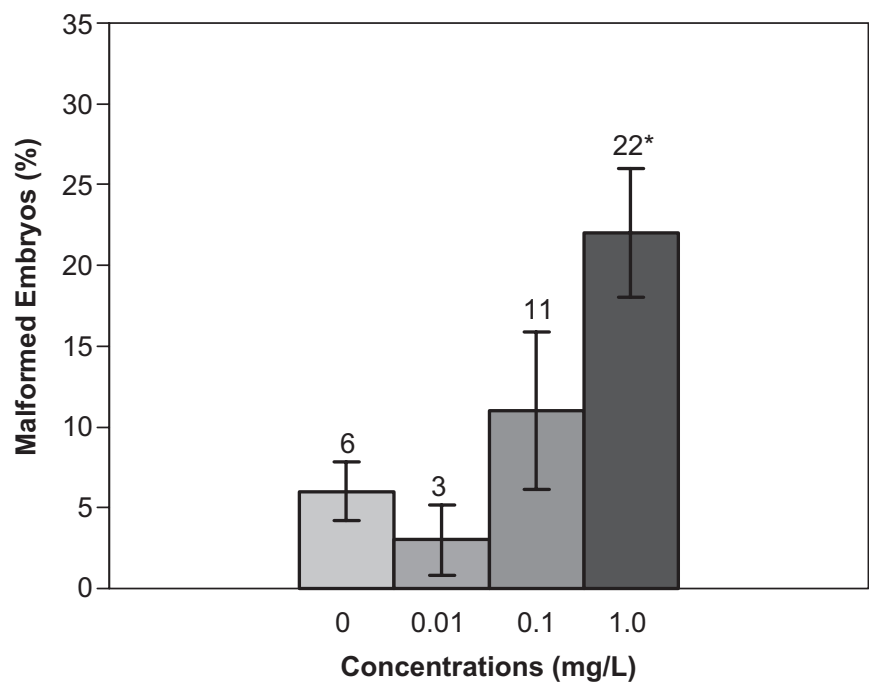

Fig. 5. Incidence of malformed embryos ( $F_{1}$ generation) exposed to nonylphenol ethoxylate $(0,0.01,0.1$, and $1.0 \mathrm{mg} / \mathrm{L})$. Proportions are means \pm S.E. of malformed embryos ((no. of malformed embryos/no. of live embryos $\times 100$ ) per egg mass recorded at the 10th day after spawning. An asterisk $(*)$ indicates that the mean differ $(p<0.05$ ANOVA and Dunnett's multiple comparisons test) from that of unexposed controls $(0 \mathrm{mg} / \mathrm{L})$.

beakers for additional 12 weeks and then, 10 individuals per concentration group, chosen at random, were separated and transferred to individual glass vessels. After separation, snail egg production was evaluated for 8 weeks. Figs. 6 and 7, therefore, show cumulative production of eggs and egg masses, respectively, per snail per concentration group during 8 weeks. NPE9.5, at the highest concentration tested, markedly reduced fecundity of $F_{1}$ generation by decreasing the number of eggs $(225.7 \pm 18.4)$ and the number of egg masses per snail $(25.1 \pm 1.5)$ as compared to those numbers recorded for unexposed controls $(398.8 \pm 27.2 ; 42.1 \pm 1.7)$. At the intermediate concentration tested $(0.1 \mathrm{mg} / \mathrm{L})$, egg production of exposed snails did not differ from that of unexposed controls either in terms of egg masses or in terms of eggs produced. At the lowest concentration tested $(0.01 \mathrm{mg} / \mathrm{L})$, however, NPE9.5 caused a statistically significant increase in the number of eggs $(486.3 \pm 20.9)$ but did not alter the number of eggmasses $(46.1 \pm 1.9)$ produced per snail (Figs. 6 and 7$)$.

\subsection{Effects on the $F_{2}$ generation: developmental toxicity}

The effect of a trans-generation exposure to NPE9.5 on the embryonic development of $B$. tenagophila was investigated in egg masses laid by $F_{1}$ snails, i.e., in $F_{2}$ snail embryos. Evaluation of the developmental toxicity of NPE9.5 in the $F_{2}$ generation of snails was conducted essentially as previously described for the $F_{1}$ generation. NPE9.5 had no lethal effect on $F_{2}$ generation embryos (Fig. 8). It induced, however, a higher incidence of malformed embryos (19\%), and a concentration-dependent augment of hatching delays at the highest concentra-

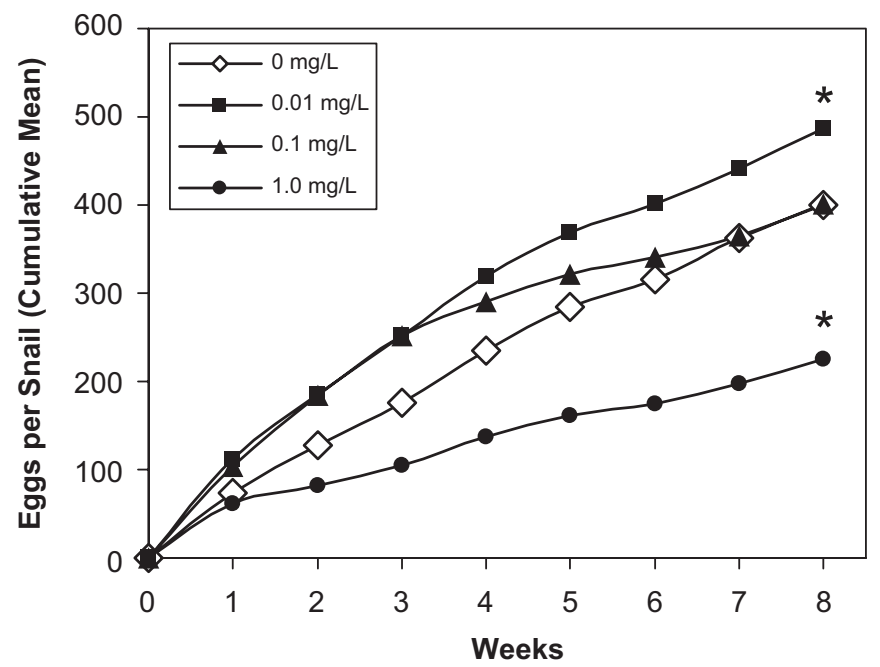

Fig. 6. Effects of nonylphenol ethoxylate with 9.5 units $(0,0.01,0.1$, and $1.0 \mathrm{mg} / \mathrm{L})$ on the number of eggs laid by mature $B$. tenagophila snails $\left(F_{1}\right.$ generation). Data are shown as cumulative means of number of eggs laid per snail during an 8 -week exposure. An asterisk $(*)$ indicates that the mean differ $(p<0.05$ ANOVA and Dunnett's multiple comparisons test) from that of unexposed controls $(0 \mathrm{mg} / \mathrm{L})$ at the 8 th week.

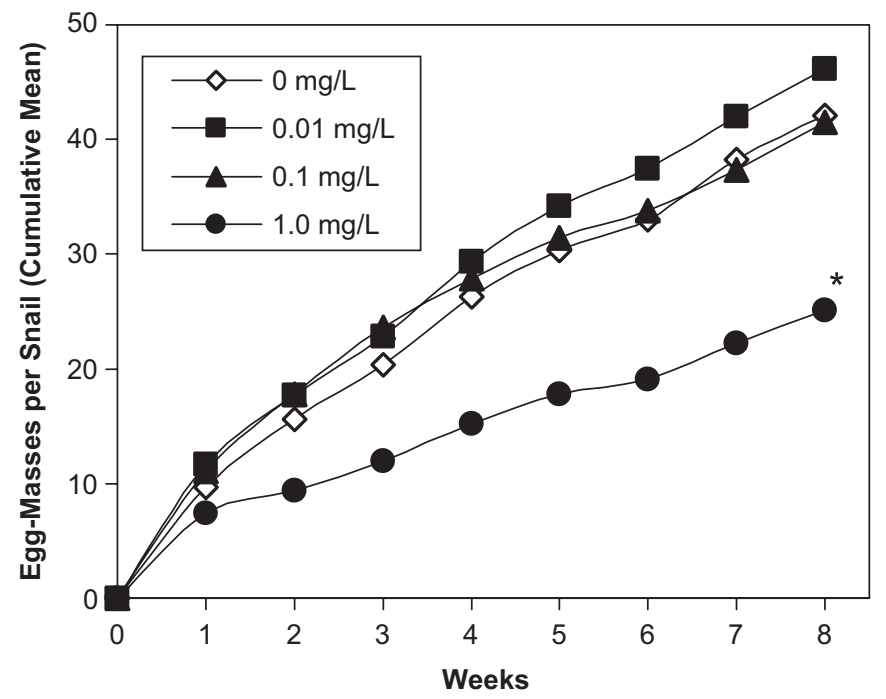

Fig. 7. Effects of nonylphenol ethoxylate with 9.5 units $(0,0.01,0.1$, and $1.0 \mathrm{mg} / \mathrm{L})$ on the number of egg masses laid by mature $B$. tenagophila snails $\left(F_{1}\right.$ generation). Data are shown as cumulative means of number of egg masses laid per snail during an 8-week exposure. An asterisk (*) indicates that the mean differ ( $p<0.05$ ANOVA and Dunnett's multiple comparisons test) from that of unexposed controls $(0 \mathrm{mg} / \mathrm{L})$ at the same week.

tion tested (Figs. 9 and 10). In contrast to a $96 \%$ of hatching success in the unexposed control group, $98 \%$ of the embryos exposed to the highest concentration, $93 \%$ of embryos exposed to the intermediate concentration, and $65 \%$ of those exposed to the lowest concentration of NPE9.5 had not yet hatched on day 10 after spawning (Fig. 10). 


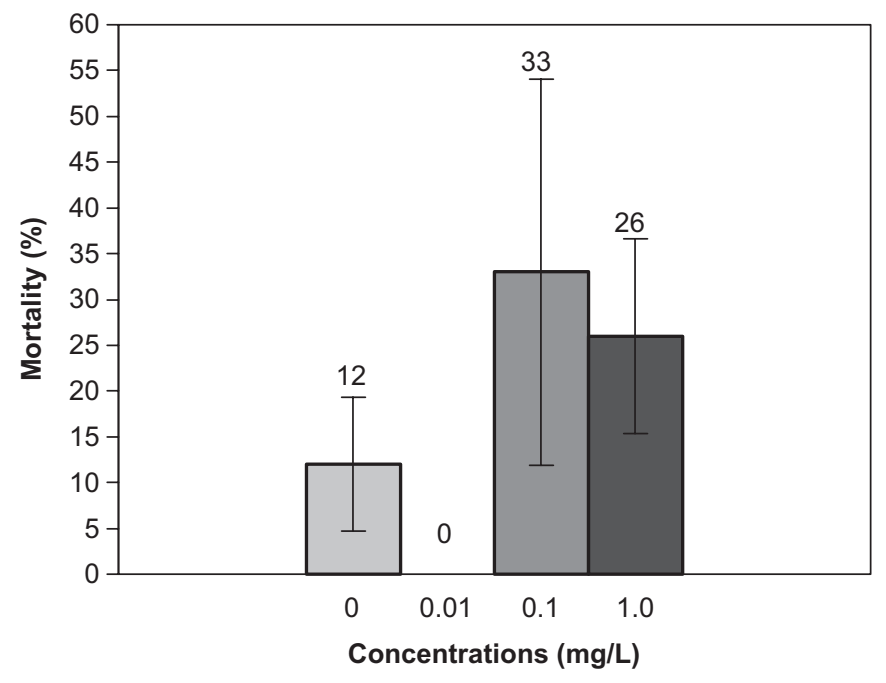

Fig. 8. Embryolethal effects of nonylphenol ethoxylate with 9.5 units $(0,0.01,0.1$, and $1.0 \mathrm{mg} / \mathrm{L})$ on B. tenagophila embryos ( $F_{2}$ generation) recorded at the 10th day after spawning. Proportions are means \pm S.E. of embryo deaths $(($ no. of deaths/no. of eggs $) \times 100)$ per egg mass. No difference was found $(p<0.05$ ANOVA and Dunnett's multiple comparisons test) between any group exposed to NPE and unexposed control group $(0 \mathrm{mg} / \mathrm{L})$.

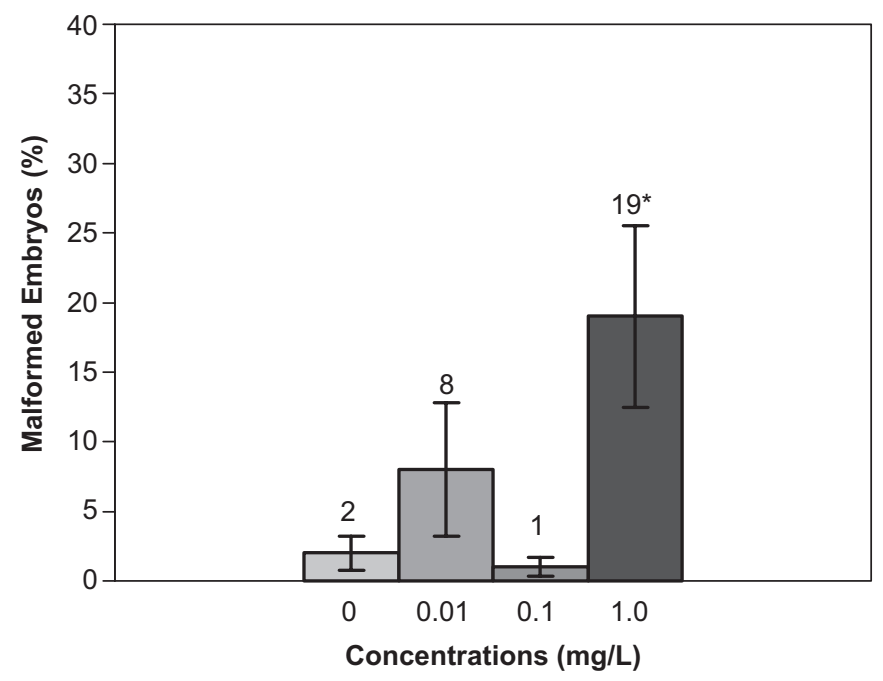

Fig. 9. Incidence of malformed embryos ( $F_{2}$ generation embryos) exposed to nonylphenol ethoxylate $(0,0.01,0.1$, and $1.0 \mathrm{mg} / \mathrm{L})$. Proportions are means \pm S.E. of malformed embryos ((no. of malformed embryos/no. of live embryos $) \times 100$ ) per egg mass recorded at the 10th day after spawning. An asterisk $(*)$ indicates that the mean differ $(p<0.05$ ANOVA and Dunnett's multiple comparisons test) from that of unexposed controls $(0 \mathrm{mg} / \mathrm{L})$.

\section{Discussion}

Exposure to sub-lethal concentrations of alkylphenolic compounds has been reported to adversely affect the reproductive performance of a variety of aquatic species including fish and invertebrates. Since alkyl-phenols possess estrogen-like effects in different animal models, impairment of reproduction could be attributed, at least in

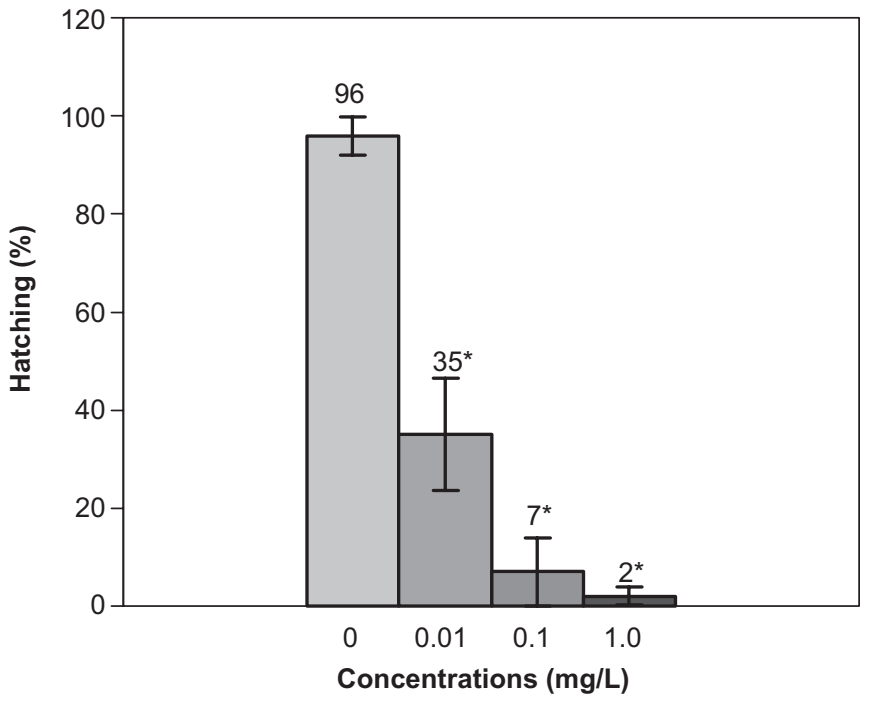

Fig. 10. Proportion of hatching until the 10th day after spawning among B. tenagophila snails ( $F_{2}$ generation embryos) exposed to nonylphenol ethoxylate with 9.5 units $(0,0.01,0.1$, and $1.0 \mathrm{mg} / \mathrm{L})$. Values are means \pm S.E. of percentages of hatching ((no. of successfully hatched snails $/$ no. of eggs $) \times 100)$ per egg mass. An asterisk $(*)$ indicates that the mean differ $(p<0.05$ ANOVA and Dunnett's multiple comparisons test $)$ from that of unexposed controls $(0 \mathrm{mg} / \mathrm{L})$.

part, to the putative endocrine-disrupting properties of these compounds. Estrogen-like effects of nonylphenol have been described in in vitro test systems (Soto et al., 1995; Shelby et al., 1996; Petit et al., 1997) as well as in several in vivo tests such as induction of vitellogenin production in male fish and alterations of reproductive organs (Shelby et al., 1996; Hemmer et al., 2001).

Most studies on the effects of alkylphenols on the reproductive performance of aquatic and terrestrial species were performed with fish, but there are also a few reports on the effects of these environmental contaminants on snails and other invertebrates. Tanaka and Nakanishi (2002), for instance, described that chronic exposure to 4nonylphenol $(0.07 \mathrm{mg} / \mathrm{L})$ reduced fecundity of the first generation of the zooplankton crustaceae Daphnia galeata. Along the same line, Shurin and Dodson (1997) noted that nonylphenol $(0.1 \mathrm{mg} / \mathrm{L})$ decreased production of females and increased the incidence of morphological anomalies in embryos of Daphnia mendotae. Widarto et al. (2007), on the other hand, reported that nonylphenol stimulated the fecundity of springtails (Folsomia candida), a common soildwelling, wingless and parthenogenetic insect. Hoss et al. (2002) found that exposure to 4-nonylphenol, in concentrations ranging from 40.2 up to $235.2 \mu \mathrm{g} / \mathrm{L}$, enhanced fecundity of the nematode Caenohabditis elegans as well.

In experiments performed with the freshwater snail Marisa cornuarietis and the marine prosobranch Nucella lapidus, Oehlmann et al. (2000) found that octylphenol induced a complex syndrome of alterations in female snails referred to as "superfemales". The "superfemale" syndrome consisted of enlargement of accessory pallial sex 
glands, anomalies of pallial oviduct, and marked stimulation of oocyte and spawning mass production. Octylphenol-caused alterations were noted at the lowest nominal concentrations tested (range 1-100 $\mu \mathrm{g} / \mathrm{L}$ ) and, as far as egg and spawning mass production are concerned, inverted U-shaped concentration response relationships were found. Oehlmann et al. (2000) also noted that the xenoestrogen bisphenol A produced-at similar nominal concentrations - essentially the same syndrome on both snails. Duft et al. (2003) reported that octylphenol, 4-nonylphenol as well as bisphenol A, stimulated embryo production in the freshwater mudsnail (Potamopyrgus antipodarum), a parthenogenetic and ovoviviparous mollusk. In contrast to the foregoing stimulatory effects of alkylphenols on snail egg production, Czech et al. (2001) found that exposure to 4-nonylphenol $(0.1 \mathrm{mg} / \mathrm{L})$ for 12 weeks decreased Lymnaea stagnalis egg-mass production. It is of note that, $B$. tenagophila and $L$. stagnalis are both hermaphrodite freshwater snails.

Results provided by the present study demonstrated that nonylphenol ethoxylate 9.5, at the two highest concentrations tested $(0.1$ and $1.0 \mathrm{mg} / \mathrm{L})$, reduced fecundity (eggs and egg masses per snail) of $B$. tenagophila parental $\left(F_{0}\right)$ generation. Fecundity was reduced among snails of $F_{1}$ generation that were exposed to the highest concentration of NPE9.5 $(1.0 \mathrm{mg} / \mathrm{L})$, but egg production of $F_{1}$ snails exposed to the intermediate concentration tested $(0.1 \mathrm{mg} /$ L) did not differ from that of non-exposed controls. Although NPE9.5, at the lowest concentration tested $(0.01 \mathrm{mg} / \mathrm{L})$ had no effect on the fecundity of $F_{0}$ generation snails, it clearly stimulated fecundity (egg production) of their descendants ( $F_{1}$ generation). The foregoing results clearly suggested that effects of NPE9.5 on snail reproduction depend on the duration of exposure and possibly also on the embryonic developmental periods during which snails were exposed. The same concentration of NPE9.5 that had no effect $(0.01 \mathrm{mg} / \mathrm{L})$ on the fecundity of mature snails exposed for 8 weeks ( $F_{0}$ generation), was clearly stimulatory for snails continuously exposed through their whole life-cycle until reproductive maturity $\left(F_{1}\right.$ generation). Along the same line, a concentration of NPE9.5 $(0.1 \mathrm{mg} / \mathrm{L})$ that had reduced fecundity of the $F_{0}$ generation had no effect on the fecundity of the subsequent $F_{1}$ generation snails.

Our results for $B$. tenagophila snails $\left(F_{0}\right)$ exposed to NPE9.5 were to some extent similar to those provided by Czech et al. (2001) for L. stagnalis exposed to NP, one of the degradation products of NPE9.5. In these studies, $0.1 \mathrm{mg} / \mathrm{L}$ of NPE9.5 (B. tenagophila exposed for 8 weeks) and $0.1 \mathrm{mg} / \mathrm{L}$ of $\mathrm{NP}$ (L. stagnalis exposed for 12 weeks) decreased fecundity of reproductively mature snails. Nonetheless, it should be borne in mind that Czech et al. (2001) investigated the effects of 4-nonylphenol and, in the present study, was used nonylphenol with 9.5 ethoxylate units.

We evaluated the developmental toxicity of NPE9.5 in $F_{1}$ and in $F_{2}$ snail embryos. A higher frequency of malformed snails revealed that, at the highest concentra- tion tested, NPE9.5 impaired the development of $F_{1}$ embryos. Besides this teratogenic effect at the highest concentration tested, no other embryotoxic effect was detected in the $F_{1}$ generation of snails. A similar augment in the incidence of malformed embryos, induced by the same concentration of NPE9.5, was noted in the $F_{2}$ generation as well. Developmental toxicity of NPE9.5 to $F_{2}$ snails was also revealed by a concentration-dependent decrease in the proportion of snails that hatched until day 10 after spawning (Fig. 10). Since no hatching retardation had been noted in the previous test with $F_{1}$ embryos, transgeneration exposure seemed to have aggravated developmental toxicity of NPE9.5. It should be pointed out that, although not being statistically different of the unexposed group, there was a trend to a higher mortality among $F_{1}$ and $F_{2}$ embryos exposed to the two highest concentrations of NPE9.5 (Figs. 3 and 8).

Octylphenols and nonylphenols have been considered as endocrine disruptors and their estrogen-like effects were observed in sexually dimorphic freshwater (M. cornuarietis) and marine ( $N$. lapidus) snails after exposure to low concentrations of these compounds (Oehlmann et al., 2000). It has also been shown that 4-nonylphenol and other putative xenoestrogens alter the reproductive performance of parthenogenetic ( $P$. antipodarum) and hermaphroditic (L. stagnalis) snails (Duft et al., 2003; Czech et al., 2001). Findings provided by the foregoing studies are consistent with the interpretation that dose-dependent stimulatory and or inhibitory effects of nonylphenol on snail egg production are mediated by a substance-produced hormonal imbalance.

Alkylphenol ethoxylates (e.g., NPEs) have also been reported to be estrogenic compounds. It was reported, for instance, that in an in vitro assay of estrogenicity (stimulation of vitellogenin gene expression in trout hepatocytes) nonylphenol diethoxylate (NPE2) was as potent as NP (White et al, 1994). In the case of alkylphenol ethoxylates, however, estrogenic activity seems to decrease with increasing ethoxylate chain length. Owing to its long ethoxylate chain, NPE9 was reported to possess estrogenic potency 30 times smaller than NPE2 (Jobling and Sumpter, 1993). Primary degradation of NPE9.5, nonetheless, generates shorter chain NPEs (e.g., NPE2) and NP which are more persistent and have been described to possess estrogenic activity (Servos, 1999). The primary degradation of nonylphenol polyethoxylates (e.g., NPE9) depends on the temperature and other factors and a half-life of 4 days in water was estimated in a river die away test (Yoshimura, 1986). Since, in the present study, the assay water was renewed twice a week, it seems fair to assume that snails were exposed not only to NPE9.5 but also to its primary degradation products.

It is not entirely clear, however, whether the developmental toxicity (teratogenicity and hatching delay) noted in the present study was due to estrogenicity or to other biological or physicochemical (e.g., surfactant) properties of nonylphenol polyethoxylates. 


\section{Conclusions}

In conclusion, under the conditions of this study, NOECs (no-observed-effect-concentration) for reproductive toxicity of nonylphenol ethoxylate 9.5 to the freshwater snail B. tenagophila were as follows: for fecundity, $F_{0}=10 \mu \mathrm{g} / \mathrm{L}, \quad F_{1}<10 \mu \mathrm{g} / \mathrm{L}$; for developmental toxicity, $F_{1}=100 \mu \mathrm{g} / \mathrm{L}, F_{2}<10 \mu \mathrm{g} / \mathrm{L}$. The NOEC for effects on reproduction obtained in the present study $(<10 \mu \mathrm{g} / \mathrm{L})$ was lower than NOECs found for nonylphenol ethoxylate with nine units in chronic assays performed with other aquatic species such as 96-h assay with Selenastrum capricornutum $(8000 \mu \mathrm{g} / \mathrm{L})$, Daphnia magna 7-day survival and reproduction assay $(10,000 \mu \mathrm{g} / \mathrm{L})$ and 7-day assay with Pimephales promelas $(1000 \mu \mathrm{g} / \mathrm{L})$ (Dorn et al., 1993). This relatively low NOEC for nonylphenol ethoxylate 9.5 found for a freshwater snail seems to support the view that mollusks are highly vulnerable to environmental contaminants, and B. tenagophila seems to be a suitable bioindicator of water contamination.

\section{Acknowledgments}

We are grateful to Dr. June Springer de Freitas and colleagues from the Department of Ecology of the University of Brasilia for allowing us to use their laboratories and also for excellent technical support. F.J.R.P. is the recipient of a research fellowship from $\mathrm{CNPq}$ (Brazilian National Research Council).

\section{References}

ABNT (Associação Brasileira de Normas Técnicas), 2004. Ecotoxicologia aquática-Toxicidade aguda-Método de ensaio com Daphnia spp (Cladocera, Crustacea). NBR 12713, Rio de Janeiro, Brasil.

Archand-Hoy, L.D., Benson, W.H., 1998. Fish reproduction: an ecologically relevant indicator of endocrine disruption. Environ. Toxicol. Chem. 17 (1), 49-57.

Bellavere, C., Gorbi, J., 1981. Comparative analysis of acute toxicity of chromium, copper and cadmium to Daphnia magna, Biomphalaria glabrata and Brachydanio rerio. Environ. Technol. Lett. 2 (3), 119-128.

Bennie, D.T., 1999. Review of the environmental occurrence of alkylphenols and alkylphenol ethoxylates. Water Qual. Res. J. Can. 34 (1), 79-122.

Czech, P., Weber, K., Dietrich, D.R., 2001. Effects of endocrine modulating substances on reproduction in the hermaphroditic snail Lymnaea stagnalis L. Aquat. Toxicol. 53, 103-114.

Depledge, M.H., Billinghurst, Z., 1999. Ecological significance of endocrine disruption in marine invertebrates. Mar. Pollut. Bull. 39 (1-12), 32-38.

Dorn, P.B., Salanitro, J.P., Evans, S.H., Kravetz, L., 1993. Assessing the aquatic hazard of some branched and linear nonionic surfactants by biodegradation and toxicity. Environ. Toxicol. Chem. 12, $1751-1762$

Duft, M., Schulte-Oehlmann, U., Weltje, L., Tillmann, M., Oehlmann, J., 2003. Stimulated embryo production as a parameter of estrogenic exposure via sediments in the freshwater mudsnail Potamopyrgus antipodarum. Aquat. Toxicol. 64, 437-449.

Freitas, J.S., Paula, D.P., Cariello, M.O., 1997. The influence of selffertilization performance and copulation behavior in reproduction by cross-fertilization in groups of Biomphalaria tenagophila (Mollusca, Planorbidae). Mem. Inst. Oswaldo Cruz 92 (6), 739-743.

Geilenkirchen, W.L.M., 1966. Cell division and morphogenesis of Lymnaea eggs after treatment with heat pulses at successive stages in early division cycles. J. Embryol. Exp. Morphol. 16 (2), 321-337.

Hemmer, M.J., Hemmer, B.L., Bowman, C.J., Kroll, K.J., Folmar, L.C., Marcovich, D., Hoglund, M.D., Denslow, N.D., 2001. Effects of pnonylphenol, methoxychlor, and endosulfan on vitellogenin induction and expression in sheepshead minnow (Cyprinodon variegatus). Environ. Toxicol. Chem. 20 (2), 336-343.

Horiguchi, T., Kojima, M., Kaya, M., Matsuo, T., Shiraishi, H., Morita, M., Adachi, Y., 2002. Tributyltin and triphenyltin induce spermatogenesis in ovary of female abalone, Haliotis gigantea. Mar. Environ. Res. 54, 679-684.

Hoss, S., Juttner, I., Traunspurger, W., Pfister, G., Schramm, K.W., Steinberg, C.E.W., 2002. Enhanced growth and reproduction of Caenorhabditis elegans (Nematoda) in the presence of 4-nonylphenol. Environ. Pollut. 120, 169-172.

Jobling, S., Sumpter, J.P., 1993. Detergent components in sewage effluent are weakly oestrogenic to fish: an in vitro study using rainbow trout (Oncorhynchus mykiss) hepatocytes. Aquat. Toxicol. 27 (3/4), 361-372.

Jobling, S., Sheahan, D.A., Osborne, J.A., Matthiessen, P., Sumpter, J.P., 1996. Inhibition of testicular growth in rainbow trout (Oncorhynchus mykiss) exposed to estrogenic alkylphenolic chemicals. Environ. Toxicol. Chem. 15 (2), 194-202.

Larsson, D.G.J., Adolfsson-Erici, M., Parkkonen, J., Pettersson, M., Berg, A.H., Olsson, P.E., Förlin, L., 1999. Ethinyloestradiol-an undesired fish contraceptive? Aquat. Toxicol. 45 (2/3), 91-97.

Maguire, R.J., 1999. Review of the persistence of nonylphenol and nonylphenol ethoxylates in aquatic environments. Water Qual. Res. J. Can. 34 (1), 37-78.

Matthiessen, P., Gibbs, P.E., 1998. Critical appraisal of the evidence for tributyltin-mediated endocrine disruption in mollusks. Environ. Toxicol. Chem. 17 (1), 37-43.

Münzinger, A., 1987. Biomphalaria glabrata (Say), a suitable organism for a biotest. Environ. Technol. Lett. 8, 141-148.

Nice, H.E., Morritt, D., Crane, M., Thorndyke, M., 2003. Long-term and transgenerational effects of nonyl phenol exposure at a key stage in the development of Crassostrea gigas: possible endocrine disruption? Mar. Ecol. Progr. Ser. 256, 293-300.

Oehlmann, J., Schulte-Oehlmann, U., Tillmann, M., Markert, B., 2000. Effects of endocrine disruptors on prosobranch snails (Mollusca: Gastropoda) in the laboratory. Part I: Bisphenol and octylphenol as xeno-estrogens. Ecotoxicology 75, 1185-1190.

Oliveira-Filho, E.C., Lopes, R.M., Paumgartten, F.J.R., 2004. Comparative study on the susceptibility of freshwater species to copper-based pesticides. Chemosphere 56, 369-374.

Oliveira-Filho, E.C., Geraldino, B.R., Grisolia, C.K., Paumgartten, F.J.R., 2005. Acute toxicity of endosulfan, nonylphenol ethoxylate, and ethanol to different life stages of the freshwater snail Biomphalaria tenagophila (Orbigny, 1835). Bull. Environ. Contam. Toxicol. 75, 1185-1190.

Petit, F., Le Goff, P., Cravedi, J.P., Valotair, Y., Pakdel, F., 1997. Two complementary bioassays for screening the estrogenic potency of xenobiotics: recombinant yeast for trout estrogen receptor and trout hepatocyte cultures. J. Mol. Endocrinol. 19, 321-335.

Porte, C., Janer, G., Lorusso, L.C., Ortiz-Zarragoitia, M., Cajaraville, M.P., Fossi, M.C., Canesi, L., 2006. Endocrine disruptors in marine organisms: approaches and perspectives. Comp. Biochem. Physiol. C Toxicol. Pharmacol. 143 (3), 303-315.

Ravera, O., 1977. Effects of heavy metals (cadmium, copper, chromium and lead) on a freshwater snail: Biomphalaria glabrata Say (Gastropoda, Prosobranchia). Malacologia 16 (1), 231-236.

Routledge, E.J., Sheahan, D., Desbrow, C., Brighty, G.C., Waldock, M., Sumpter, J.P., 1998. Identification of estrogenic chemicals in STW effluent. 2. In vivo responses in trout and roach. Environ. Sci. Technol. 32 (11), 1559-1565. 
Servos, M.R., 1999. Review of the aquatic toxicity, estrogenic responses and bioaccumulation of alkylphenols and alkylphenol polyethoxylates. Water Qual. Res. J. Can. 34 (1), 123-177.

Shelby, M.D., Newbold, R.R., Tully, D.B., Chae, K., Davis, V.L., 1996. Assessing environmental chemicals for estrogenicity using a combination of in vitro and in vivo assays. Environ. Health Perspect. 104, 1296-1300.

Shurin, J.B., Dodson, S.I., 1997. Sublethal effects of cyanobacteria and nonylphenol on environmental sex determination and development in Daphnia. Environ. Toxicol. Chem. 16, 1269-1276.

Soto, A.M., Sonnenschein, C., Chung, K.L., Fernandez, M.F., Olea, N., Serrano, F.O., 1995. The E-SCREEN assay as a tool to identify estrogens: an update on estrogenic environmental pollutants. Environ. Health Perspect. 103 (Suppl.), 113-122.
Tanaka, Y., Nakanishi, J., 2002. Chronic effects of p-nonylphenol on survival and reproduction of Daphnia galeata: multigenerational life table experiment. Environ. Toxicol. 17, 487-492.

Widarto, T.H., Krogh, P.H., Forbes, V.E., 2007. Nonylphenol stimulates fecundity but not population growth rate $(\lambda)$ of Folsomia candida. Ecotoxicol. Environ. Saf. 67 (3), 369-377.

Willey, J.B., Krone, P.H., 2001. Effects of endosulfan and nonylphenol on the primordial germ cell population in pre-larval zebrafish embryos. Aquat. Toxicol. 54, 113-123.

White, R., Jobling, S., Hoare, S.A., Sumpter, J.P., Parker, M.G., 1994. Environmentally persistent alkylphenolic compounds are estrogenic. Endocrinology 135, 175-182.

Yoshimura, K., 1986. Biodegradation and fish toxicity of nonionic surfactants. J. Am. Oil Chem. Soc. 63, 1590-1596. 